\title{
Brachyuran and anomuran crabs associated with Schizoporella unicornis (Ectoprocta, Cheilostomata) from southeastern Brazil
}

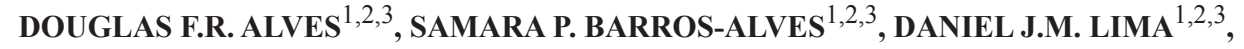 \\ VALTER J. COBO ${ }^{2,3}$ and MARIA LUCIA NEGREIROS-FRANSOZO ${ }^{1,2}$ \\ ${ }^{1}$ Universidade Estadual Paulista/UNESP, Departamento de Zoologia, \\ Instituto de Biociências, Distrito de Rubião Junior, s/n, 18618-970 Botucatu, São Paulo, Brasil \\ ${ }^{2}$ NEBECC Study Group on Crustacean Biology, Ecology and Culture, Distrito de Rubião Junior, \\ s/n, 18618-970 Botucatu, São Paulo, Brasil \\ ${ }^{3}$ Laboratório de Biologia Marinha, LabBMar, Instituto de Biociências, Universidade de Taubaté/UNITAU, \\ Av. Tiradentes, 500, Centro, 12030-180 Taubaté, SP, Brasil \\ Manuscript received on August 23, 2011; accepted for publication on April 27, 2012
}

\begin{abstract}
The main goals of this investigation were to describe the community structure of anomuran and brachyuran crabs inhabiting reefs constituted by colonies of Schizoporella unicornis, and to provide a species importance ranking for this community. Collections were carried out on S. unicornis reefs at two-month intervals from May 2003 to May 2004, in the rocky sublittoral of the southeastern Brazilian coast. Relative abundance and occurrence were used to rank these species in the hierarchy importance. A total of 2,018 individuals were obtained, in 11 families, 22 genera and 31 species. Porcellanidae and Pilumnidae were the most abundant families, comprising respectively almost $60 \%$ and $15 \%$ of individuals sampled. The species ranking indicated four main groups A, B, C and D, with group A subdivided. Subgroup A1 contained 9 species, including the species of greatest ecological importance for community regarding abundance and occurrence. The great abundance of crabs associated with $S$. unicornis seems to be the result of its recognized importance during the crab developmental cycle, and as shelter and food for some Decapod species. These observations reveal the importance of conserving the areas occupied by these reef colonies, which appear to be an important environment for maintaining local biodiversity.
\end{abstract}

Key words: biogenic substrata, bryozoan, community structure, decapods, symbiotic species.

\section{INTRODUCTION}

Sessile invertebrates including some corals, ectoprocts, polychaetes and mollusks are commonly recognized as biogenic substrata builders, which are exploited by a large epibiont fauna (Gore et al. 1978, Bradstock and Gordon 1983, Safriel and Ben-Eliahu 1991, Thompson et al. 1996). On these biogenic

Correspondence to: Samara de Paiva Barros-Alves

E-mail: barros_samara@hotmail.com habitats, the associated fauna find shelter and food and thus a safe site for reproduction and development (Safriel and Eliahu-Ben 1991, Porras et al. 1996).

Decapods occur in association with certain sessile invertebrates such as sponges (Porras et al. 1996, Caruso et al. 2005), corals and anemones (Humes 1991, Arvanitides and Koukouras 1994), worm tubes (Nalesso et al. 1995, Sepúlveda et al. 2003, Nascimento and Torres 2006), echinoderms 
(Wirtz et al. 2009) and bryozoans (Ferdeghini et al. 2000, Morgado and Tanaka 2001). However, some decapod groups seem to be preferentially associated with certain biogenic substrata, where they can reach high abundances, which may mean a close relationship among these associated species (e.g., sponges with pilumnid crabs and alpheid shrimps; Sargassum beds with epialtid crabs; Phragmatopoma reefs with porcellanid crabs, among others) (Micheletti-Flores and Negreiros-Fransozo 1999, Széchy et al. 2001, Bosa and Masunari 2002, Ribeiro et al. 2003). Exact knowledge of which species are involved in these symbiotic relationships could provide biological and ecological information concerning these decapods, and also regarding the traits of the supposed dependence relationships between the decapods and their biogenic substrata.

Species of the genus Schizoporella Hincks, 1877 are bryozoan ectoprocts of the family Schizoporellidae, which build calcareous reefs on hard substrates, forming shelters for a variety of invertebrate fauna, including decapod crustaceans. Some investigators have reported on these associations involving decapods and Schizoporella reefs, mainly on United States and Brazilian coasts, such as Lindberg (1980), Lindberg and Frydenborg (1980), Lindberg and Stanton (1988, 1989), Mantelatto and Souza-Carey (1998a, b) and Morgado and Tanaka (2001).

Schizoporella unicornis (Johnston 1847) is a sessile cosmopolitan bryozoan, it is distributed along the Brazilian coast with records in Northeast, Southeast and South (Farrapeira 2011). The colonies of $S$. unicornis have an orange structure with a variety of branched shapes, occurring due to interactions with other organisms and the local hydrodynamic condition (Cocito et al. 2000, Ferdeghini et al. 2000). These colonies grow in intertidal zones, on rocky substrates or on pier columns, and can reach up to $25 \mathrm{~cm}$ height (Ross and McCain 1976).
This contribution characterizes the community structure of the anomuran and brachyuran crabs living on reefs of $S$. unicornis in a small bay on the southeastern Brazilian coast. The following population parameters of decapods were also analyzed: abundance, occurrence, size and sex ratio. In order to evaluate the symbiotic species with $S$. unicornis, the level of importance to this community was evaluated by means of the occurrence and relative abundance of the species.

\section{MATERIALS AND METHODS}

Collections of $S$. unicornis reefs were carried out at two-month intervals from May 2003 to May 2004. The reefs studied were growing on pier columns at Itaguá Beach in Ubatuba, northeastern coast of São

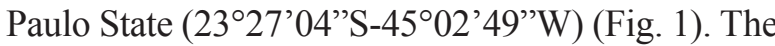
reefs were collected by hand, by divers working during the daytime. The catch per unit effort consisted of one person scanning the bottom for reefs, for each two months.

The material (bryozoan colonies) collected was bagged during the dive to avoid the loss of specimens, and transferred to the Marine Biology Laboratory at the Universidade de Taubate -

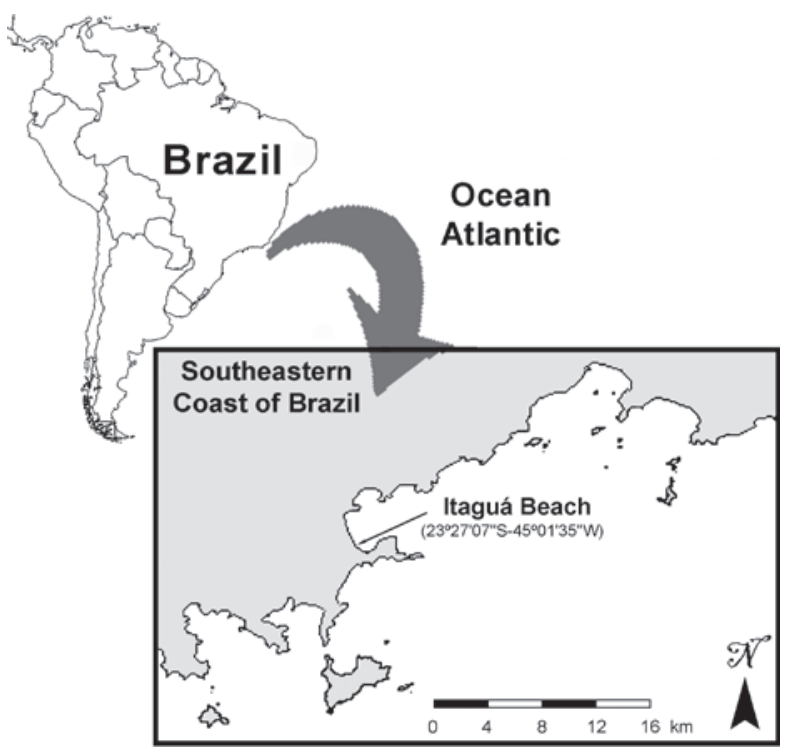

Fig. 1 - Map of the northeastern coast of São Paulo showing Itaguá Beach. 
UNITAU, where the decapods were separated from the colonies. The crabs were identified according to Melo (1996, 1999), and their classification followed $\mathrm{Ng}$ et al. (2008).

Sex and developmental stage (juvenile or adult) of the brachyuran crabs were identified from the external morphology of the abdomen and appendages. The sex determination for anomurans was based on the gonopore position (females on the coxa of the third pereiopod and males on the coxa of the fifth pereiopod), and the individuals were identified as juvenile or adult considering the size of the smallest ovigerous females obtained in the samples. For those species, which no ovigerous females was recorded, the size of smallest ones obtained by Litulo (2005) and Miranda and Mantelatto (2009) was used. The sex ratio was estimated and tested by Chi-square $(\mathrm{p}<0.05)(Z a r 1999)$. The largest carapace width $(\mathrm{CW})$ was measured for brachyuran and porcellanid crabs, and the shield length (SL) for hermit crabs.

The relative abundance (RAb) was calculated for each crab species as $R A b=n / N$, where $n=$ total absolute abundance recorded for a given species, and $\mathrm{N}=$ total of the individuals recorded over the entire sampling program. The relative occurrence (RO) was represented as $\mathrm{RO}=\mathrm{p} / \mathrm{P}$, where $\mathrm{p}$ $=$ number of samples containing in the given species, and $\mathrm{P}=$ the total number of samples. In order to estimate the similarity of species present in the community, these species were grouped according to Bray-Curtis similarity index, followed by UPGMA cluster method (Zar 1999), where the indexes (RAb and RO) were employed as parameters to build the cluster. This similarity analysis recognizes set of species concerning their ecological importance for community.

Only the most important species (showed by grouping analyses) were included in the analyses of median size of individuals, sex ratio and frequency histograms.

\section{RESULTS}

During the field surveys, 2,018 individuals were collected, distributed in 11 families, 22 genera and 31 species of anomuran and brachyuran decapods. Identification at species level was not possible for 78 specimens, which were recognized only to family level (Table I). The porcellanid anomuran crabs Megalobrachium roseum, Pachycheles monilifer and Pisidia brasiliensis were the most abundant species, with 409, 297 and 179 individuals captured, respectively. The brachyuran crabs Pelia rotunda, Microphrys antillensis, Hexapanopeus paulensis, and the anomuran crab Calcinus tibicen, Pachycheles riisei and Petrolisthes amoenus were represented by only one specimen each (Table I).

The most abundant families were Porcellanidae and Pilumnidae, comprising respectively around $60 \%$ and $15 \%$ of the total decapods collected. These porcellanid crabs also showed the highest species richness, contributing 9 of the total species found in association with the reef colonies (Table I).

The species ranking indicated four groups (A, $\mathrm{B}, \mathrm{C}$, and D) composed of 15, 3, 5 and 8 species respectively. Group A was subdivided into subgroups A1 and A2 (Fig. 2). The species belonging to groups $\mathrm{C}$ and $\mathrm{D}$ showed the lowest relative abundance and occurrence, while group B species were recorded in intermediate abundance and occurrence, and species of group A were the most important in relative abundance and occurrence.

Subgroup A1 was composed of 9 species, Megalobrachium roseum, Pachycheles monilifer, Petrolisthes galathinus, Pisidia brasiliensis, Menippe nodifrons, Mithraculus forceps, Pilumnus reticulatus, Pilumnus spinosissimus, Paguristes tortugae (Fig. 2). This subgroup included 5 anomurans and 4 brachyurans. The species of this subgroup A1 were used in further analysis.

The size-class distribution frequency analysis showed that brachyuran and anomuran crab community was constituted mainly by small 
TABLE I

Brachyuran and anomuran species associated with Schizoporella unicornis and their respective abbreviations (Cod); absolute abundance (N); sex ratio (Male: Female); relative abundance (RAb); relative occurrence (RO).

\begin{tabular}{|c|c|c|c|c|c|c|c|}
\hline \multirow{2}{*}{ Family/species } & \multirow{2}{*}{ Cod } & \multirow{2}{*}{$\mathrm{N}$} & \multicolumn{2}{|c|}{ Size $(\mathrm{mm})$} & \multirow{2}{*}{$\mathrm{M}: \mathrm{F}$} & \multirow{2}{*}{$\mathrm{RAb}$} & \multirow{2}{*}{$\mathrm{RO}$} \\
\hline & & & Range & $\mathrm{X} \pm \mathrm{SD}$ & & & \\
\hline \multicolumn{8}{|l|}{ MENIPPIDAE } \\
\hline Menippe nodifrons Stimpson, 1859 & Mno & 80 & $2.50-24.80$ & $7.68 \pm 4.07$ & $1: 1.4$ & 0.04 & 1.00 \\
\hline \multicolumn{8}{|l|}{ EPIALTIDAE } \\
\hline Epialtus bituberculatus H. Milne Edwards, 1834 & Ebi & 3 & $2.20-8.10$ & $5.90 \pm 3.22$ & $1: 0.5$ & 0.00 & 0.33 \\
\hline Apiomithrax violaceus (A. Milne Edwards, 1868) & Avi & 12 & $2.50-16.20$ & $6.13 \pm 4.21$ & $1: 1$ & 0.01 & 0.83 \\
\hline Pelia rotunda A. Milne Edwards, 1875 & Pro & 1 & 6.50 & - & - & 0.00 & 0.17 \\
\hline \multicolumn{8}{|l|}{ INACHIDAE } \\
\hline Podochela gracilipes Stimpson, 1871 & Pgr & 54 & $2.10-6.50$ & $3.72 \pm 0.88$ & $1: 1.6$ & 0.03 & 0.83 \\
\hline Stenorhynchus seticornis (Herbst, 1788) & Sse & 5 & $2.10-12.10$ & $6.98 \pm 4.57$ & $1: 4$ & 0.00 & 0.50 \\
\hline MAJIDAE & & 3 & & & & & \\
\hline Microphrys antillensis Rathbun, 1901 & Man & 1 & 4.50 & - & - & 0.00 & 0.17 \\
\hline Microphrys bicornutus (Latreille, 1825) & Mbi & 2 & $2.10-4.10$ & $3.10 \pm 1.41$ & $1: 1$ & 0.00 & 0.33 \\
\hline Mithraculus forceps (A. Milne Edwards, 1875) & Mfo & 35 & $3.10-11.90$ & $7.33 \pm 2.42$ & $1: 1.2$ & 0.02 & 1.00 \\
\hline Mithrax hispidus (Herbst, 1790) & Mhi & 6 & $7.60-12.20$ & $9.42 \pm 1.82$ & $1: 1$ & 0.00 & 0.67 \\
\hline PILUMNIDAE & & 48 & & & & & \\
\hline Pilumnus diomedeae Rathbun, 1894 & Pdi & 2 & $3.60-4.40$ & $4.00 \pm 0.57$ & $1: 1$ & 0.00 & 0.33 \\
\hline Pilumnus reticulatus Stimpson, 1860 & Pre & 152 & $1.90-13.20$ & $4.48 \pm 2.29$ & $1: 1.3$ & 0.08 & 1.00 \\
\hline Pilumnus spinosissimus Rathbun, 1898 & Psp & 160 & $2.10-9.50$ & $4.61 \pm 1.48$ & $1: 1.1$ & 0.09 & 1.00 \\
\hline PORTUNIDAE & & 2 & & & & & \\
\hline Cronius ruber (Lamarck, 1818) & $\mathrm{Cru}$ & 3 & $3.60-27.20$ & $13.4 \pm 12.3$ & $1: 0.5$ & 0.002 & 0.33 \\
\hline PANOPEIDAE & & 20 & & & & & \\
\hline Acantholobulus bermudensis Benedict \& Rathbun, 1891 & Abe & 57 & $2.20-6.80$ & $3.89 \pm 0.70$ & $1: 0.7$ & 0.03 & 0.83 \\
\hline Hexapanopeus paulensis Rathbun, 1930 & Hрa & 1 & 6.50 & - & - & 0.00 & 0.17 \\
\hline Panopeus americanus Saussure, 1857 & Pme & 5 & $2.90-3.50$ & $3.24 \pm 0.27$ & $1: 4$ & 0.00 & 0.17 \\
\hline Panopeus rugosus A. Milne Edwards, 1880 & Pru & 2 & $3.40-6.50$ & $4.95 \pm 2.19$ & $1: 1$ & 0.00 & 0.33 \\
\hline \multicolumn{8}{|l|}{ GRAPSIDAE } \\
\hline Pachygrapsus transversus (Gibbes, 1850) & Ptr & 36 & $2.40-6.30$ & $3.18 \pm 0.96$ & $1: 2.6$ & 0.02 & 0.67 \\
\hline \multicolumn{8}{|l|}{ PAGURIDAE } \\
\hline Pagurus brevidactylus (Stimpson, 1859) & $\mathrm{Pbv}$ & 20 & $1.20-2.40$ & $1.80 \pm 0.40$ & $1: 1.1$ & 0.00 & 0.50 \\
\hline \multicolumn{8}{|l|}{ DIOGENIDAE } \\
\hline Calcinus tibicen (Herbst, 1791) & $\mathrm{Cti}$ & 1 & 2.20 & - & - & 0.00 & 0.17 \\
\hline Paguristes tortugae Schmitt, 1933 & Pto & 128 & $0.70-6.00$ & $3.00 \pm 1.30$ & $1: 2.6$ & 0.07 & 1.00 \\
\hline PORCELLANIDAE & & 5 & & & & & \\
\hline Megalobrachium roseum (Rathbun, 1900) & Mro & 409 & $1.30-5.90$ & $3.50 \pm 0.92$ & $1: 1.1$ & 0.21 & 1.00 \\
\hline Megalobrachium soriatum (Say, 1818) & Mso & 86 & $1.40-4.60$ & $3.10 \pm 0.69$ & $1: 0.9$ & 0.04 & 0.67 \\
\hline Pachycheles laevidactylus Ortmann, 1892 & Pla & 46 & $1.60-4.80$ & $3.37 \pm 0.72$ & $1: 0.9$ & 0.02 & 0.50 \\
\hline Pachycheles monilifer (Dana, 1852) & Pmo & 297 & $1.50-9.20$ & $4.31 \pm 1.57$ & $1: 0.8$ & 0.16 & 1.00 \\
\hline Pachycheles riisei (Stimpson, 1858) & Pri & 1 & 2.70 & - & - & 0.00 & 0.17 \\
\hline Petrolisthes amoenus (Guérin-Menéville, 1855) & Pam & 1 & 3.40 & - & - & 0.00 & 0.17 \\
\hline Petrolisthes armatus (Gibbes, 1850) & Par & 2 & $3.70-4.30$ & $4.00 \pm 0.42$ & $2: 0$ & 0.00 & 0.17 \\
\hline Petrolisthes galathinus (Bosc, 1802) & Pga & 83 & $1.40-8.50$ & $4.65 \pm 1.8$ & $1: 0.7$ & 0.04 & 1.00 \\
\hline Pisidia brasiliensis Haig in Rodrigues da Costa, 1968 & Pbr & 179 & $1.70-4.90$ & $3.41 \pm 0.68$ & $1: 1.2$ & 0.09 & 1.00 \\
\hline
\end{tabular}




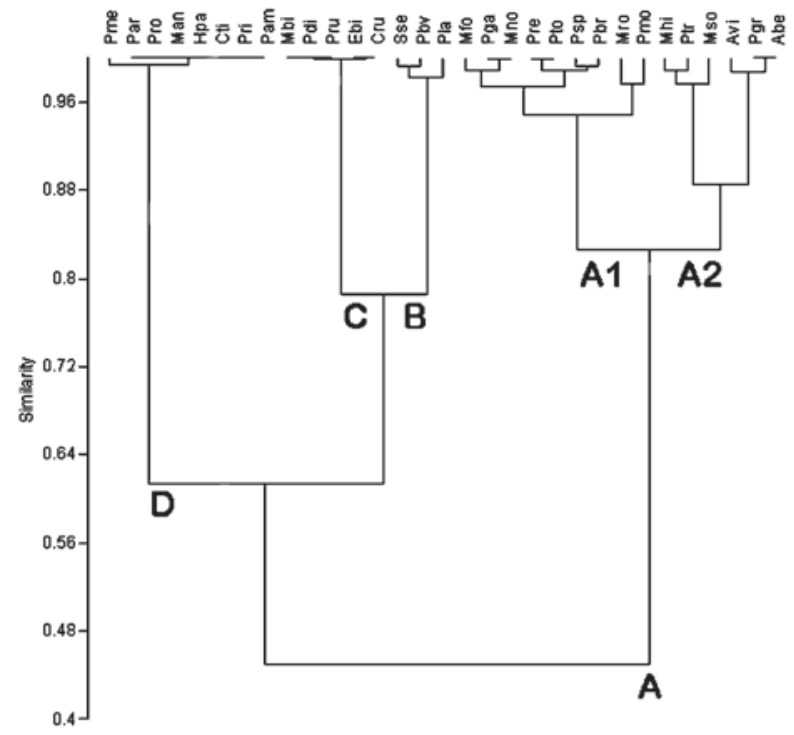

Fig. 2 - Cluster analysis (UPGMA - Bray-Curtis), similarity between the relative occurrence and abundance of species obtained in association with Schizoporella unicornis in Ubatuba, southeastern Brazil. The species codes are found in Table I.

specimens (Table I). In the subgroup A1, anomurans were mainly distributed from the first to third size class, except for Pachycheles monilifer e Petrolisthes galathinus that were recorded for larger size classes, (Fig. 3A-E). Among brachyuran crabs the maximum size reached was included into the 12.1-14.0 $\mathrm{mmCW}$ size class, with exception to Menippe nodifrons that was the largest decapod recorded during the present study (Fig. 3F-I).

Of these species, only Menippe nodifrons was not recorded in all demographic categories, being represented mainly by juveniles (Fig. 4A, B). Meaningful deviations from the Mendelian sex ratio were found only for Paguristes tortugae, biased toward females $\left(1: 2.61, \chi^{2}=22.32 ; p<0.001\right)$.

Some small individuals of Menippe nodifrons, Pilumnus reticulatus, Pilumnus spinosissimus and Paguristes tortugae could not be sexed, and were included in the analyses as "sex undetermined" (Figure 4A, B).

\section{DISCUSSION}

The richness recorded for Brachyura and Anomura (19 and 12 species, respectively) associated with
Schizoporella unicornis is larger than in previous reports. According to Lindberg and Stanton (1988) Schizoporella pungens that occurs only from the north-eastern Gulf of Mexico and Yucatan Peninsula, found 11 species of brachyurans and 5 species of anomurans. Mantelatto and SouzaCarey (1998a, b) found 20 brachyuran species and 9 anomuran species in their study on $S$. unicornis realized at Itaguá Beach in Ubatuba, southeastern Brazil (Table II). This number of species is larger than those found by investigations of other biogenic substrata along the Brazilian coast (Bosa and Masunari 2002, Ribeiro et al. 2003, Chintiroglou et al. 2004). Structural complexity and abundance might explain differences among studies and remain to be studied in the future (Witman 1985, Thiel and Baeza 2001).

The anomuran and brachyuran crabs recorded in this investigation were characterized by their small adult body size (e.g., P. gracilipes, $P$. tortugae, $M$. roseum), or presence of juveniles of species reaching large body sizes (e.g., $M$. nodifrons, C. ruber, M. hispidus) and therefore exploit the reefs only in their initial development stages. Taking into account that portunids are considered predators (Warner 1977, Nevis et al. 2009), Cronius ruber, which has recorded the largest mean size, can use $S$. unicornis colonies as feeding site, where it can get its prey.

The internal spaces in the reef colonies can also be used by the motile fauna from adjacent substrata, which exploit these colonies as a refuge or/and food resource. Some authors such as Jones et al. (1994) and Chintiroglou et al. (2004) have categorized the sessile fauna as "engineer species" that are able to increase the heterogeneity and tridimensionality of the habitat.

The reef colonies of $S$. unicornis provide refuge sites at the milimetric scale, which seems to be important for the first settlement of certain crabs, that will grow to larger sizes, as seen in Table III. The colonies of $S$. unicornis function as a nursery 

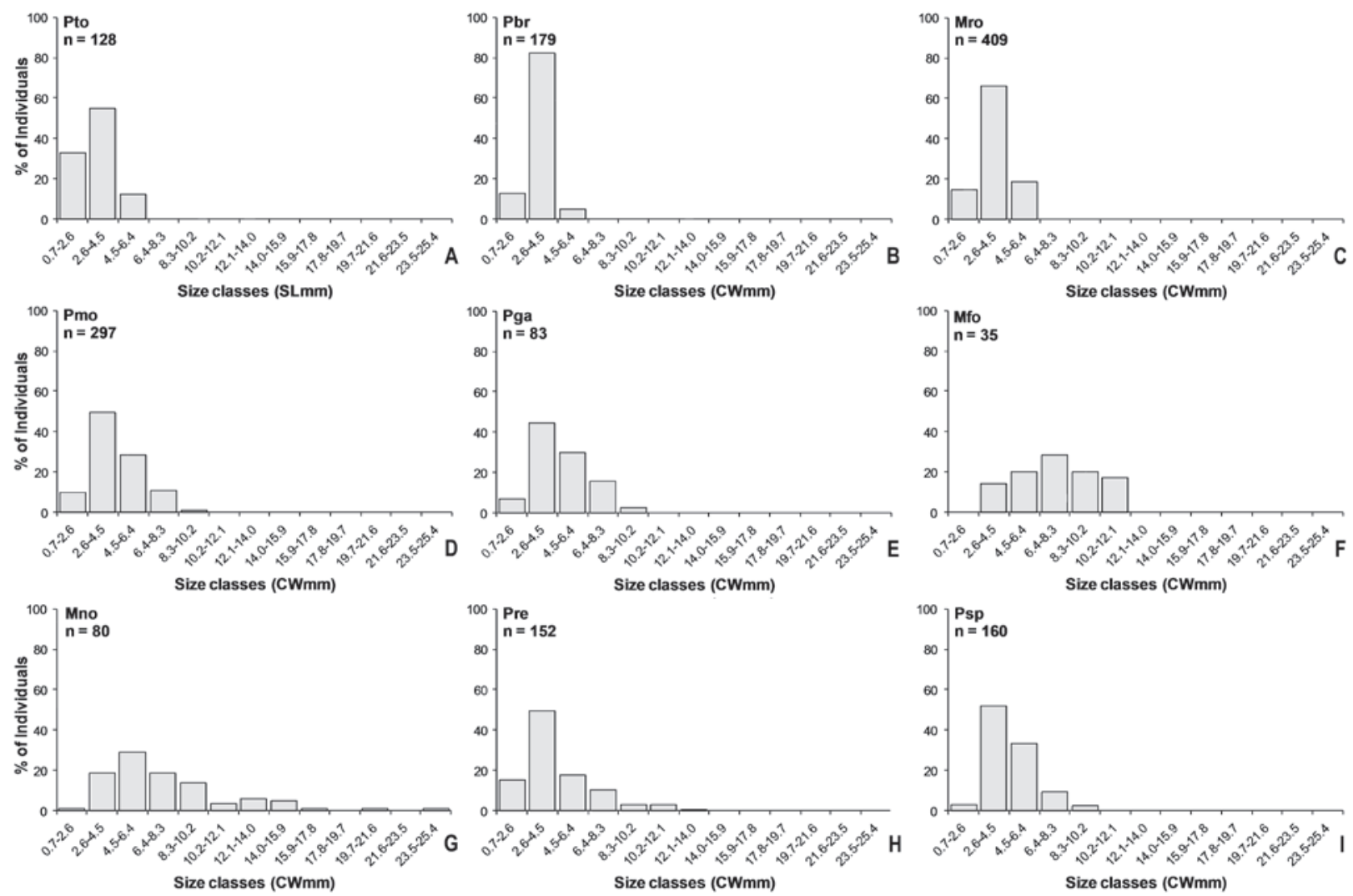

Fig. 3 - Size-frequency distribution of specimens of anomurans (A-E) and brachyurans (F-I). The species codes are found in Table I.
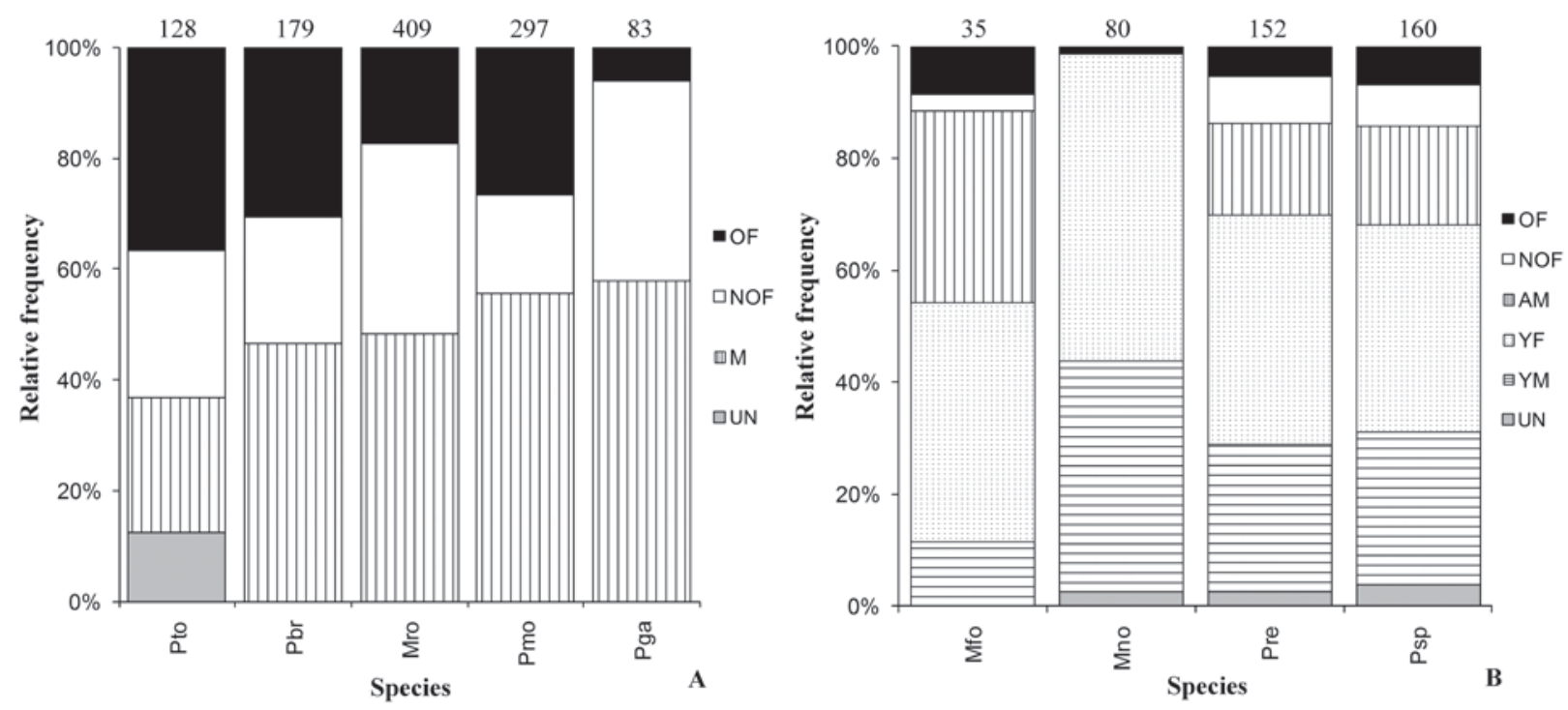

Fig. 4 - Relative frequency of specimens by group of anomuran (A) and brachyuran (B) species associated with Schizoporella unicornis. M= males; $\mathrm{UN}=$ undetermined; $\mathrm{OF}=$ ovigerous females; $\mathrm{NOF}=$ non-ovigerous adult females; $\mathrm{YF}=$ young females; $\mathrm{AM}=$ adult males; $\mathrm{YM}=$ young males. The number above the bars represents the absolute abundance of the species. The species codes are found in Table I. 
TABLE II

Studies reporting the association of decapods (Brachyura and Anomura) with Schizoporella colonies, noting the richness of species and the most abundant species found in each study.

\begin{tabular}{|c|c|c|c|c|c|c|}
\hline Author/year & Location & $\begin{array}{c}\text { Species of } \\
\text { Schizoporella }\end{array}$ & $\begin{array}{c}\text { Richness } \\
\text { Brachyura }\end{array}$ & $\begin{array}{l}\text { Most Abundant } \\
\text { Species }\end{array}$ & $\begin{array}{l}\text { Richness } \\
\text { Anomura }\end{array}$ & Most Abundant Species \\
\hline $\begin{array}{l}\text { Lindberg and } \\
\text { Stanton } 1988\end{array}$ & Florida, USA & $\begin{array}{c}\text { Schizoporella } \\
\text { pungens Canu \& } \\
\text { Bassler, } 1928\end{array}$ & 11 & $\begin{array}{l}\text { Pilumnus sayi } \\
\text { Rathbun, } 1923\end{array}$ & 5 & $\begin{array}{c}\text { Porcellana sayana } \\
\text { (Leach, 1820), Pagurus } \\
\text { brevidactylus, Petrolisthes } \\
\text { armatus }\end{array}$ \\
\hline $\begin{array}{c}\text { Mantelatto and } \\
\text { Souza-Carey 1998a }\end{array}$ & $\begin{array}{c}\text { Ubatuba, } \\
\text { Southeastern Brazil }\end{array}$ & S. unicornis & - & - & 9 & Pachycheles monilifer \\
\hline $\begin{array}{c}\text { Mantelatto and } \\
\text { Souza-Carey 1998b }\end{array}$ & $\begin{array}{c}\text { Ubatuba, } \\
\text { Southeastern Brazil }\end{array}$ & S. unicornis & 20 & $\begin{array}{l}\text { Pachygrapsus } \\
\text { transversus }\end{array}$ & - & - \\
\hline \multirow{2}{*}{$\begin{array}{l}\text { Morgado and } \\
\text { Tanaka } 2001\end{array}$} & $\begin{array}{c}\text { Ubatuba, } \\
\text { Southeastern } \\
\text { Brazil }\end{array}$ & Schizoporella & 10 & $\begin{array}{c}\text { Acantholobulus } \\
\text { schmitti (Rathbun, } \\
\text { 1930) }\end{array}$ & 4 & $\begin{array}{c}\text { Pachycheles rugimanus } \\
\text { Milne-Edwards, } 1880\end{array}$ \\
\hline & $\begin{array}{c}\text { São Sebastião, } \\
\text { Southeastern Brazil }\end{array}$ & 1878) & 4 & $\begin{array}{c}\text { Pilumnus } \\
\text { dasypodus } \\
\text { Kingsley, } 1879\end{array}$ & 4 & Pachycheles rugimanus \\
\hline Present study & Southeastern Brasil & S. unicornis & 19 & $\begin{array}{c}\text { Pilumnus } \\
\text { spinosissimus }\end{array}$ & 12 & Megalobrachium roseum \\
\hline
\end{tabular}

TABLE III

Comparison of maximum sizes $(\mathrm{mm})$ of the brachyuran and anomuran species recorded in this study and in the literature. Note: only species with 5 or more specimens were included in this analysis.

\begin{tabular}{|c|c|c|c|}
\hline Species & Present study & Literature & Reference \\
\hline Menippe nodifrons & 24.8 & 129.0 & Williams 1984 \\
\hline Apiomithrax violaceus & 16.2 & 21.0 & Melo 1998 \\
\hline Podochela gracilipes & 6.5 & 10.9 & Melo 1998 \\
\hline Stenorhynchus seticornis & 12.1 & 24.0 & Williams 1984 \\
\hline Mithraculus forceps & 11.9 & 38.0 & Williams 1984 \\
\hline Mithrax hispidus & 12.2 & 146.0 & Williams 1984 \\
\hline Pilumnus reticulatus & 13.2 & 13.3 & Melo 1998 \\
\hline Pilumnus spinosissimus & 9.5 & 11.0 & Melo 1998 \\
\hline Acantholobulus bermudensis & 6.8 & 9.6 & Melo 1998 \\
\hline Panopeus americanus & 3.5 & 24.3 & Melo 1998 \\
\hline Pachygrapsus transversus & 6.3 & 26.4 & Williams 1984 \\
\hline Pagurus brevidactylus & 2.2 & 6.7 & Melo 1999 \\
\hline Paguristes tortugae & 5.0 & 19.3 & Melo 1999 \\
\hline Megalobrachium roseum & 5.9 & 4.3 & Melo 1999 \\
\hline Megalobrachium soriatum & 4.6 & 5.5 & Williams 1984 \\
\hline Pachycheles laevidactylus & 4.8 & 8.5 & Melo 1999 \\
\hline Pachycheles monilifer & 9.2 & 11.0 & Melo 1999 \\
\hline Petrolisthes galathinus & 8.5 & 9.2 & Melo 1999 \\
\hline Pisidia brasiliensis & 4.9 & 5.3 & Melo 1999 \\
\hline
\end{tabular}


ground for several of the species recorded in this study, as it provides the largest number of refuges for crabs ranging from 2.7 to $5.1 \mathrm{~mm} \mathrm{CW}$.

The identification of substrate features such as texture can be a determining factor for decapod crustacean larval establishment and the stimuli for metamorphoses that take the individuals to the juvenile life stage (Anger 2006). The large number of individuals that could not be identified to species level because of their small sizes suggests the importance of these bryozoan colonies for the establishment and juvenile development of at least some species.

The overall ranking of species importance in the community for the data obtained during entire the sampling period showed that $9(29 \%)$ species of subgroup A1 are temporary or permanent residents on the $S$. unicornis reefs. All the species of this group were recorded in all samples, which were found in all demographic categories and in similar sizes to those mentioned in the literature; except for M. nodifrons (see Table III).

The data for $M$. nodifrons and $P$. reticulatus suggest that $S$. unicornis does not provide appropriate conditions for their entire life cycle, because after the modal class their frequencies declined. M. nodifrons may reach $130 \mathrm{~mm} \mathrm{CW}$ (Williams 1984) (see Table III), and is a common inhabitant of intertidal rocky shores along the entire Brazilian coast (Melo 1996). Juveniles of $M$. nodifrons were reported occupying $S$. unicornis reefs by Mantelatto and Souza-Carey (1998b) and Morgado and Tanaka (2001). During its development, this crab can exploit different biogenic substrata on intertidal rocky shores, especially for food and refuge (see Fransozo et al. 2000, Oshiro 1999). The results of this investigation agree with this pattern, since the specimens captured were no larger than $25 \mathrm{~mm} \mathrm{CW}$, suggesting that colonies of $S$. unicornis provide favorable sites only for immature M. nodifrons.

Subgroup A1 was composed of a filter-feeding component including porcellanid crabs (4 species)
(Trager et al. 1992, Achituv and Pedrotti 1999); an omnivorous component with one hermit-crab species (Reese 1969) and 2 brachyuran species; and an herbivorous component with 2 brachyuran species, represented by 2 majoid crabs (Stachowicz and Hay 1996). In addition, the size-class frequency distribution in size classes of individuals for these 9 species indicated a trend to a normal and unimodal distribution, suggesting that these species may spend their entire post-embryonic life history associated with $S$. unicornis reefs.

The juveniles of $P$. tortugae were difficult to sex, and therefore individuals in this stage were classified as "sex undetermined". External sex identification is based on the presence of a gonopore, but these apertures are only conspicuous after sexual maturity. The same difficulty was reported by NegreirosFransozo and Fransozo (1992) and Mantelatto and Dominciano (2002).

The species of subgroup A1 might be characterized as symbiotic with $S$. unicornis on the southeastern Brazilian coast. Of these, M. nodifrons has only a temporary relationship, exploiting these reefs during its juvenile development.

Subgroup A1 included both anomurans and brachyurans, specially Pilumnidae and Porcellanidae species, in agreement to Lindberg and Stanton (1988), whereby Pilumnus sayi and Porcellana sayana were the most abundant decapods in Florida, USA, and Morgado and Tanaka (2001) that founded Pilumnus dasypodus and Pachycheles rugimanus as the most abundant species for southeastern Brazil. Mantelatto and Souza-Carey (1998a) also reporting Pachycheles monilifer as the most abundant Anomuran associated with S.unicornis in the southeastern Brazilian coast (see Table II). On the other hand, unlike the finds of the present study, Pachygrapsus transversus was recognized by Mantelatto and Souza-Carey (1998b) as the most abundant Brachyuran in the S. unicornis colonies, as shown in Table II.

Those findings indicate that Schizoporella sp colonies would be an opportunistic shelter for 
decapods. The dominance of porcellanids was likely constrained by their suspension- or detritusfeeding habit (Trager et al. 1992, Achituv and Pedrotti 1999). On the other hand, Kyomo (1999) reported Pilumnus vespertilio (Fabricius 1793) as omnivorous, tending to herbivory, and a common feeding habit among brachyurans (see Hill 1976, Barros et al. 2008). Although pilumnids and porcellanids shared the same habitat and were both abundant, they avoid competition by exploiting different food sources.

The subgroup A2 species may be visitors or residents that show some degree of seasonality, and were separated from group A1 by the relative occurrence of these groups. The remaining species, belonging to groups $\mathrm{B}, \mathrm{C}$ and $\mathrm{D}$, were less abundant or accidental. This situation of minimal frequency may have different biological meanings, such as cryptic behavior, migration and dispersal, or even the influence of the adjacent habitats, which might reduce the frequency of individuals and also the catch efficiency (Witman 1985, Bertness 1999) in addition to the natural self-regulation that drives the community structure and determines the size of the populations in the community. However, these statements must be viewed as speculations that still require empirical confirmation.

Additionally, it is possible that the species $M$. roseum, P. monilifer and Pisidia brasiliensis are characteristic of the $S$. unicornis habitat, mainly as a consequence of their filter-feeding habit and because of the wide range of food resources available in the area. Bryozoans are also filterfeeders, and therefore, the sites where they settle are obviously suitable for other filter-feeding animals (Cocito et al. 2000).

Seasonal alterations in the population density of key species belonging to subgroup A1 can modify the dominance patterns of the community and cause oscillations in competition for refuges and/ or food. Nevertheless, the period of highest diversity is the same as observed in other studies of decapod communities on the southeastern Brazilian coast (e.g. Mantelatto and Fransozo 2000, Mantelatto et al. 2004). This period may be associated with the larger amounts of organic matter made available by the incursion of the South Atlantic Central Waters (SACW) in these coastal regions (Arasaki 2004, Santos and Pires-Vanin 2004).

The rich decapod fauna found associated with S. unicornis indicates the contribution of these reef colonies to the ontogenetic development of these crabs. These findings reveal the importance of conservation of the areas occupied by these reefs, which appear to be an important environment for local biodiversity stocks.

\section{ACKNOWLEDGMENTS}

The authors are indebted to Janet W. Reid, PhD, for her constructive comments on early drafts of the manuscript and great help with the English language. The authors are indebted to their colleagues of the LabBMar - UNITAU, for help during the field surveys. All sampling in this study has been conducted in accordance with applicable state and federal laws. This study was supported by the Universidade de Taubaté (Process \# 251/2001-PRPPG).

\section{RESUMO}

Os principais objetivos deste estudo foram descrever a estrutura da comunidade de caranguejos anomuros e braquiúros que habitam recifes constituídos por colônias de Schizoporella unicornis, e fornecer uma ordenação das espécies mais importantes para esta comunidade. As coletas foram realizadas bimestralmente desde maio de 2003 até maio de 2004, no infralitoral rochoso da costa sudeste brasileira. A abundância e ocorrência relativas foram usadas para ordenar estas espécies em hierarquia de importância. Obteve-se um total de 2.018 indivíduos, distribuídos em 11 famílias, 22 gêneros e 31 espécies. Porcellanidae e Pilumnidae foram as famílias mais abundantes, 
compreendendo, respectivamente, cerca de $60 \%$ e $15 \%$ dos indivíduos amostrados. A ordenação das espécies indicou quatro grupos principais $\mathrm{A}, \mathrm{B}, \mathrm{C}$ e $\mathrm{D}$, sendo o grupo A subdividido em dois. O subgrupo A1 contém 9 espécies, incluindo as espécies de maior importância ecológica para a comunidade, com relação à abundância e ocorrência. A grande abundância de caranguejos encontrados associados com S. unicornis é resultado de sua importância reconhecida durante o ciclo de desenvolvimento, e como abrigo e alimento para algumas espécies de decápodos. Estas observações revelam a importância de conservar as áreas ocupadas por essas colônias de briozoários, que parece ser um ambiente importante para a manutenção da biodiversidade local.

Palavras-chave: substrato biogênico, briozoário, estrutura da comunidade, decápodos, espécies simbióticas.

\section{REFERENCES}

AchituV Y AND Pedrotti ML. 1999. Costs and gains of porcelain crab suspension feeding in different flow conditions. Mar Ecol Prog Ser 184: 161-169.

ANGER K. 2006. Contributions of larval biology to crustacean research: a review. Invertebr Reprod Dev 49(3): 175-205.

ARASAKI E, Muniz P AND PIRES-VANIN AM. 2004. A Functional analysis of the benthic macrofauna of the São Sebastião Channel (Southeastern Brazil). Mar Ecol 25(4): 249-263.

Arvanitides C AND Koukouras A. 1994. Polychaete fauna associated with the coral Cladocora caespitosa (L.) in the eastern Mediterranean. Mem Mus Nat Hist Nat Ser A 162: 347-353.

BARROS SP, COBO VJ AND FrAnSOZO A. 2008. Feeding habits of the spider crab Libinia spinosa H. Milne Edwards, 1834 (Decapoda, Brachyura) in Ubatuba Bay, São Paulo, Brazil. Braz Arch Biol Techn 51(2): 413-417.

BERTNESS MD. 1999. The Ecology of Atlantic Shorelines. Sinauer: Sunderland, $417 \mathrm{p}$.

Bosa CR AND MASUnARI S. 2002. Crustáceos decápodos associados aos bancos de Phragmatopoma caudata (Kröyer) (Polychaeta, Sabellariidae) na Praia de Caiobá, Matinhos, Paraná. Rev Bras Zool 19(Supl. 1): 117-133.

BRADSTOCK M AND GORDON DP. 1983. Coral-like bryozoan growths in Tasman Bay, and their protection to conserve commercial fish stocks. N Z J Mar Freshw Res 17: 159-163.

CARUSO T, FALCIAI L AND ZUPO V. 2005. Do hermit crabs like living in sponges? Paguristes eremita and Suberites domuncula: biometric data from the southern Mediterranean Sea. J Mar Biol Ass U K 85: 1353-1357.
Chintiroglou CC, Damianidis P, Antoniadou C, LANTZOUNI M AND VAFIDIS D. 2004. Macrofauna biodiversity of mussel bed assemblages in Thermaikos Gulf (northern Aegean Sea). Helgoland Mar Res 58: 62-70.

Cocito S, Ferdeghini F, Morri C And Bianchi CN. 2000. Patterns of bioconstruction in the cheilostome bryozoan Schizoporella errata: the influence of hydrodynamics and associated biota. Mar Ecol Prog Ser 192: 153-161.

FARRAPEIRA CMR. 2011. Macrobenthic invertebrates found in Brazilian coast transported on abiogenic solid floating debris. J Integr Coastal Rec 11(1): 85-96.

Ferdeghini F, Cocito S, Morri C AND BIANCHI CN. 2000 Living bryozoan buildups: Schizoporella errata (Waters, 1848) (Cheilostomatida, Ascophorina) in the northwestern Mediterranean (preliminary observations). In: Herrera CA and Jackson JBC (Eds), Proceedings of the $11^{\text {th }}$ International Bryozoology Association Conference: Panama, p. 238-244.

Fransozo A, BERTINI G AND CORRÊA MOD. 2000. Population biology and habitat utilization of the stone crab Menippe nodifrons Stimpson, 1859 (Decapoda, Xanthidae) in Ubatuba region, Brazil. In: Vaupel-Klein JC and Schram FR (Eds), The Biodiversity Crisis and Crustacea. A.A. Balkema/Rotterdam: Crustacean Issues, p. 275-281.

Gore RH, ScotTo LE AND Becker LJ. 1978. Community composition, stability, and trophic partitioning in decapod crustaceans inhabiting some tropical sabellariid worm reefs. Bull Mar Sci 28(2): 221-248.

HILL BJ. 1976. Natural food, foregut clearance rate and activity of the crab Scylla serrata. Mar Biol 34: 109-116.

HumES AG. 1991. Copepoda associated with the scleractinian coral genus Montipora in the Indo-Pacific. Proc Biol Soc Wash 104(1): 101-137.

JONES CG, LAWTON JH AND SHACHAK M. 1994. Organisms as ecosystem engineers. Oikos 69: 373-386.

KYOMO J. 1999. Feeding patterns, habits and food storage in Pilumnus vespertilio (Brachyura: Xanthidae). Bull Mar Sci 65(2): 381-389.

LINDBERG WJ. 1980. Patterns of resource use within a population of xanthid crabs occupying bryozoan colonies. Oecologia 46: 338-342.

LINDBERG WJ AND FRYDENBORG RB. 1980. Resource centered agonism of Pilumnus sayi (Brachyura, Xanthidae), an associate of the bryozoan Schizoporella pungens. Behaviour 75: $235-250$.

LINDBERG WJ AND STANTON GR. 1988. Bryozoan-associated decapod crustaceans: community patterns and a case of cleaning symbiosis between a shrimp and crab. Bull Mar Sci 42(3): 411-423.

LINDBERG WJ AND STANTON GR. 1989. Resource quality, dispersion and mating prospects for crabs occupying bryozoan colonies. J Exp Mar Biol Ecol 128: 257-282.

Litulo C. 2005. Population biology and fecundity of the Indo-Pacific hermit crab Clibanarius longitarsus (Anomura: Diogenidae). J Mar Biol Ass U K 85: 121-125. 
Mantelatto FlM, Biagi R, FARia FCR, MEIRELES AL AND MELO GAS. 2004. Checklist on brachyuran fauna (Decapoda) from infralittoral rocky/sandy bottom of Anchieta Island, São Paulo State, Brazil. Nauplius 12(2): 135-142.

Mantelatto FLM And Dominciano LCC. 2002. Pattern of shell utilization by the hermit crab Paguristes tortugae (Diogenidae) from Anchieta Island, southern Brazil. Sci Mar 66(3): 265-272.

MANTELATTO FML AND Fransozo A. 2000. Brachyuran community in Ubatuba Bay, northern coast of São Paulo State, Brazil. J Shellfish Res 19(2): 701-709.

Mantelatto FLM And SouZA-CAREY MM. 1998a. Caranguejos anomuros (Crustacea, Decapoda) associados à Schizoporella unicornis (Bryozoa, Gymnolaemata) em Ubatuba (SP), Brasil. Anais do IV Simpósio de Ecossistemas Brasileiros ACIESP 2(104): 200-206.

Mantelatto FML AND Souza-CARey MM. 1998b. Brachyura (Crustacea, Decapoda) associated to Schizoporella unicornis (Bryozoa, Gymnolaemata) in Ubatuba Bay (SP), Brazil. Braz Arch Biol Techn 41(2): 212-217.

MELo GAS. 1996. Manual de Identificação dos Crustacea Decapoda do Litoral Brasileiro. São Paulo: Plêiade/FAPESP, 640 p.

MElo GAS. 1999. Manual de Identificação dos Crustacea Decapoda do Litoral Brasileiro: Anomura; Thalassinidea; Palinuridea e Astacidea. São Paulo: Plêiade/FAPESP, 551 p.

MicheletTi-Flores CV AND Negreiros-Fransozo ML. 1999. Porcellanid crabs (Crustacea, Decapoda) inhabiting sand reefs built by Phragmatopoma lapidosa (Polychaeta, Sabellariidae) at Paranapuã Beach, São Vicente, SP, Brazil. Rev Bras Biol 59(1): 63-73.

MIRANDA I AND MANTELATTO FL. 2009. Estimating population features of the anomuran crab Petrolisthes armatus (Porcellanidae) in a remaining and impacted mangrove area of the western Atlantic. J Nat Hist 43(33-34): 2027-2039.

MorgAdo EH AND TANAKA MO. 2001. The macrofauna associated with the bryozoan Schizoporella errata (Walters) in southeastern Brazil. Sci Mar 65(3): 173-181.

NALesso RC, DuARte LFL, PIERozzi JRI AND ENUMo EF. 1995. Tube epifauna of the polychaete Phyllochaetopterus socialis Claparède. Est Coast Shelf Sci 41: 91-100.

NASCIMENTO EE AND TORRES MFA. 2006. Macroinvertebrados associados a agregados de tubos de Nicolea uspiana Nogueira, 2003 (Polychaeta, Terebellidae) nos recifes da Praia de Boa Viagem, Recife - Pernambuco. Bol Tec Cient CEPENE 14(2): 9-15.

NEGREIROS-FRANSOZO ML AND FRANSOZO A. 1992. Estrutura populacional e relação com a concha em Paguristes tortugae Schmitt, 1933 (Decapoda, Diogenidae), no litoral norte do Estado de São Paulo, Brasil. Naturalia 17: 31-42.

Nevis AB, Martinelli JM, Carvalho ASS and NAhum VJI. 2009. Abundance and spatial-temporal distribution of the family Portunidae (Crustacea, Decapoda) in the Curuçá estuary on the northern coast of Brazil. Braz J Aquat Sci Technol 13(1): 71-79.
NG PKL, Guinot D AND DAVIE PJF. 2008. Systema brachyurorum: Part I. An annotated checklist of extant brachyuran crabs of the world. Raffles Bull Zool 17: 1-208.

OSHIRO LMY. 1999. Aspectos reprodutivos do caranguejo guaiá, Menippe nodifrons Stimpson (Crustacea, Decapoda, Xanthidae) da Baía de Septiba, Rio de Janeiro, Brasil. Rev Bras Zool 16(3): 827-834.

Porras R, Bataller JV, Murghi E AND TORREgrosa MT. 1996. Trophic-structure and community composition of polychaetes inhabiting some Sabellaria alveolata (L.) reefs along the Valencia Gulf Coast, Western Mediterranean. Mar Ecol 17: 583-602.

REESE ES. 1969. Behavioral adaptations of intertidal hermit crabs. Am Zool 9: 343-355.

RibeIRo SM, OMENA EP AND MuRICY G. 2003. Macrofauna associated to Mycale microsigmatosa (Porifera, Demospongiae) in Rio de Janeiro State, SE Brazil. Est Coast Shelf Sci 57: 951-959.

Ross JRP AND MCCAIN KW. 1976. Schizoporella unicornis (Ectoprocta) in Coastal Waters of Northwestern United States and Canada. Northwest Sci 50(3): 160-171.

SAFRIEL UN AND BEN-EliaHU MN. 1991. The influence of habitat structure and environmental stability on the species diversity of polychaetes in vermetid reefs. In: Bell SS, McCoy ED and Mushinsky HR (Eds), Habitat Structure - The Physical Arrangement of Objects in Space. London: Chapman and Hall, p. 349-369.

SANTOS MFL AND PIRES-VANIN AMS. 2004. Structure and dynamics of the macrobenthic communities of Ubatuba bay, southeastern Brazilian coast. Braz J Oceanogr 52(1): 59-73.

Sepúlveda RD, Moreno RA AND CARrasco FD. 2003. Diversidad de macroinvertebrados asociados a arrecifes de Phragmatopoma moerchi Kinberg, 1867 (Polychaeta: Sabellariidae) en el intermareal rocoso de Cocholgüe, Chile. Gayana 67(1): 45-54.

STACHOWICZ JJ AND HAY ME. 1996. Facultative mutualism between an herbivorous crab and a coralline alga: advantages of eating noxious seaweeds. Oecologia 105(3): 377-387.

SzÉCHY MTM, Veloso VG AND PAUlA EJ. 2001. Brachyura (Decapoda, Crustacea) of phytobenthic communities of the sublittoral region of rocky shores of Rio de Janeiro and São Paulo, Brazil. Trop Ecol 42(2): 231-242.

THIEL M AND BAEZA JA. 2001. Factors affecting the social behaviour of crustaceans living symbiotically with other marine invertebrates: a modelling approach. Symbiosis 30: 163-190.

THOMPSON RC, WILSON BJ, TOBIN ML, HILL AS AND HAWKINS SJ. 1996. Biologically generated habitat provisioning and diversity of rocky shore organisms at a hierarchy of spatial scales. J Exp Mar Biol Ecol 202: 73-84.

Trager GC, Coughlin D, Genin A, Achituv Y AND GANGOPADHYAY A. 1992. Foraging to the rhythm of ocean waves: porcelain crabs and barnacles synchronize feeding motions with flow oscillations. J Exp Mar Biol Ecol 164: 73-86. 
WARNER GF. 1977. The biology of crabs. Elek Science London: New York, 202 p.

Williams AB. 1984. Shrimps, Lobsters, and Crabs of the Atlantic Coast of the Eastern United States, Maine to Florida. Washington: Smithsonian Institution Press, $550 \mathrm{p}$.

Wirtz P, Melo G AND GRAVE S. 2009. Symbioses of decapod crustaceans along the coast of Espírito Santo, Brazil. Mar Biodivers Rec 2: 1-9.
WITMAN JD. 1985. Refuges, biological disturbance, and rocky subtidal community structure in New England. Ecol Monogr 55(4): 421-445.

ZAR JH. 1999. Biostatistical Analysis. $4^{\text {th }}$ edition. Upper Saddle River, New Jersey. Prentice-Hall, 662 p. 